\title{
AC 2009-1930: DEFINING THE ROLE OF THE FACULTY ADVISOR IN A MECHANICAL ENGINEERING CAPSTONE DESIGN COURSE
}

\section{Gregory Watkins, California State University, Chico}

Gregory Watkins received a B.S. in Mechanical Engineering from North Carolina State University, a Master of Engineering Management from Old Dominion University, and a Ph.D. in Mechanical Engineering from the University of North Carolina at Charlotte. He is an assistant professor in the department of mechanical engineering, mechatronic engineering, and manufacturing technology at California State University Chico. He previously taught in the Engineering Technology department at UNC Charlotte and the Engineering Technologies Division at Central Piedmont Community College. He also has nine years of industrial work experience. 


\title{
Defining the Role of the Faculty Advisor in a Mechanical Engineering Capstone Design Course
}

\begin{abstract}
The mechanical engineering program at California State University Chico utilizes a two-semester capstone course in senior design project. Project work is accomplished in groups, which are assigned a single faculty advisor for the duration of the project.

Senior exit surveys, along with substantial anecdotal evidence, have repeatedly identified advisement of senior projects as a problem area in the curriculum. A strong recurring theme in the results has been a lack of understanding of exactly what the faculty advisor's role should be.

Department faculty worked to clearly define the role of the faculty advisor in the capstone design course. Goals of the effort included a clearer understanding of the advisor's role by students (and faculty), more consistent advising across groups, and a better overall design experience.

A new paradigm of design project advisement was implemented during the 2008-2009 academic year. To assess its effectiveness, the previous year's students were surveyed on their perceptions of the role of the faculty advisor, as well as the advisor's overall effectiveness. The survey was repeated for this year's students, providing feedback about the success of the new model.
\end{abstract}

\section{Overview of Senior Design Project}

As with many engineering programs, the mechanical and mechatronic engineering curricula at California State University Chico utilize a two-semester capstone course in senior design project. The intent is for students to utilize competencies developed in the first three years of the curriculum in the solution of a real-world design problem. The fall semester is predominantly spent in design activities, while the spring encompasses prototype building and testing. Projects may come from local industry, may be competition based, or may come from other sources.

During the fall semester, weekly lectures are given that cover many aspects of the design process. Selected topics include customer requirements and specifications, conceptual design, decision making, project management, cost estimating, budgets, documentation and formal reports. Each project group is required to give three oral presentations during the semester. The presentation topics are project proposal, midterm review, and final design. The semester concludes with submission of a comprehensive design report.

The spring semester includes less time in the classroom and more spent building and testing the designs. Students are required to develop a comprehensive test plan to prove the specifications developed in the fall semester. They then fabricate and test the design, and in most cases, proceed directly to redesign activities. The semester concludes with a final oral presentation, a poster and display of the prototype, and submission of a comprehensive written report. 
The design projects are accomplished by student groups, as the ability to work in groups is one of the measured outcomes of the course. Groups typically number about four, but may vary based on the complexity of the assigned project. Groups may be made up entirely of mechanical engineering majors, or may also include mechatronic majors depending on the technical aspects of the project. Regardless, each group is assigned a single faculty advisor for the duration of the project, considered by many to be a critical element ${ }^{1}$ of the student's design experience.

\section{Past Issues}

In the past, the role of the faculty advisor has not been well defined. Many advisors took the approach that they were there to assist the students only on an as-needed basis. A prevailing attitude conveyed to the students was "come by if you need anything." Assistance was generally restricted to technical aspects of the project within the expertise areas of the individual faculty members. Other advisors took a more active role in the projects, including scheduling regular group meetings, requiring weekly progress reports, and overseeing construction and testing. But this would be considered the exception rather than the norm. It is safe to say that very little coaching $^{2}$ of the groups by the faculty advisor was occurring.

As a part of standard assessment activities, the department administers exit surveys to all graduating seniors. For many years, these surveys, along with substantial anecdotal evidence, have repeatedly identified advisement of senior projects as a problem area in the curriculum. Numerous issues have been identified, illustrating that current advisement practices were at best uneven, and at worse severely lacking.

\section{Fixing the Problem}

In order to address this clear deficiency in the program, the department faculty began what turned out to be a year-long process of defining the role of the faculty advisor in the capstone design course. Goals of the effort included a clearer understanding of the advisor's role by students (as well as faculty), more consistent advising across groups, and a better overall design experience for the students. Many issues were discussed during the process, with eventual resolution to everyone's agreement. Primary issues that surfaced during the discussions were:

- Frequency of meetings with student groups

- Content of group meetings

- Project management role

- Overall responsibility for project success

- Grading responsibilities

- Review and input of student's design logbooks

- Approval of milestones

- Attendance at presentations and other events

As a result of this process, three documents were developed to clearly define the role of the faculty advisor and to implement the new paradigm in the course. The documents, included in appendices A through C respectively, are Responsibilities for Senior Project Faculty Advisors, Faculty Advisor Meeting Log Sheet, and Faculty Advisor Approvals Form. 


\section{The Role of the Faculty Advisor}

The first major decision was to establish and define weekly meetings between advisors and student groups. It was decided that weekly meetings are appropriate and necessary, particularly during the more critical fall semester, when design is accomplished. An every-other-week schedule was considered sufficient for the spring, when build and test activities take place.

In the new paradigm, advisors have a scheduled meeting at the same time each week for each project team they are advising. This meeting time is built into the faculty member's schedule and is documented on his/her door card. At each meeting, advisors review the group's Gantt chart $^{3}$ (once it has been developed), and review each student's design log book. The meeting is documented on the Faculty Advisor Meeting Log Sheet (Appendix B), including items discussed as well as outstanding issues and action items.

Another major element of the new paradigm is the Faculty Advisor Approvals Form (Appendix C). There are numerous milestones throughout the course, and it was felt that the faculty advisor should have approval authority of major milestones before the project could proceed. Fall semester milestones requiring an advisor's signature include customer requirements and specifications, and the three presentations (proposal, midterm review, and final design). Spring semester signature milestones are final bill of material, group test plan, and final design presentation.

Another major topic of discussion was grade input and responsibility. Most felt that the advisor should have significant input into a student's course grade. This gives the advisor additional clout with the students, but also means an increased work load for the advisor. For reference, the grade breakdown for the fall and spring semester courses is included in appendix D. Note that "T" and "I" indicate team vs. individual student grades.

It was decided that all of the advisors would have input for all group's presentation grades, which total $30 \%$ in the fall and $15 \%$ in the spring. Additional fall grade input includes draft design report completeness (5\%), contribution to the project (25\%), and overall project quality (20\%). Additional grade input during the spring includes individual test plan (10\%), group testing (10\%), contribution to the project (20\%), and overall project quality (20\%). Finally, at the end of each semester, all advisors grade a final design report from a group other than the one they are advising.

Regarding day to day project management and overall project success, it was decided that the advisors would not have specific responsibilities in these areas. They should have an eye on overall progress, how the team is working together, and other issues, but should clearly communicate to the students that their role is not the project manager, nor is ultimate project success their responsibility.

\section{The Results}

The new paradigm of design project advisement was implemented during the 2008-2009 academic year. To assess its effectiveness, the previous year's students were surveyed on their 
perceptions of the role of the faculty advisor, as well as their advisor's overall effectiveness. The survey was then repeated for this year's students, the first to utilize the new model. The survey (appendix E) solicited standard Likert scale ${ }^{4}$ responses to five questions, and also provided room for written comments. The survey questions are shown in Table 1 below.

Table 1 - Survey Questions

\begin{tabular}{|l|l|}
\hline Q1 & \begin{tabular}{l} 
I have a clear understanding of the role of a senior project faculty advisor \\
\hline Q2
\end{tabular} \\
\hline $\begin{array}{l}\text { I have generally been pleased with the support provided by the faculty } \\
\text { advisor of our project }\end{array}$ \\
\hline Q3 & $\begin{array}{l}\text { The faculty advisor was clearly interested in our project and did whatever } \\
\text { he/she could to help ensure its success }\end{array}$ \\
\hline With a few exceptions, we met weekly or at least every other week with \\
\hline Q5 & The faculty advisor contributed greatly to the success of our project \\
\hline
\end{tabular}

The "before" survey was completed by 48 of 49 students in the class. Figure 1 shows the number of students responding in each Likert category.

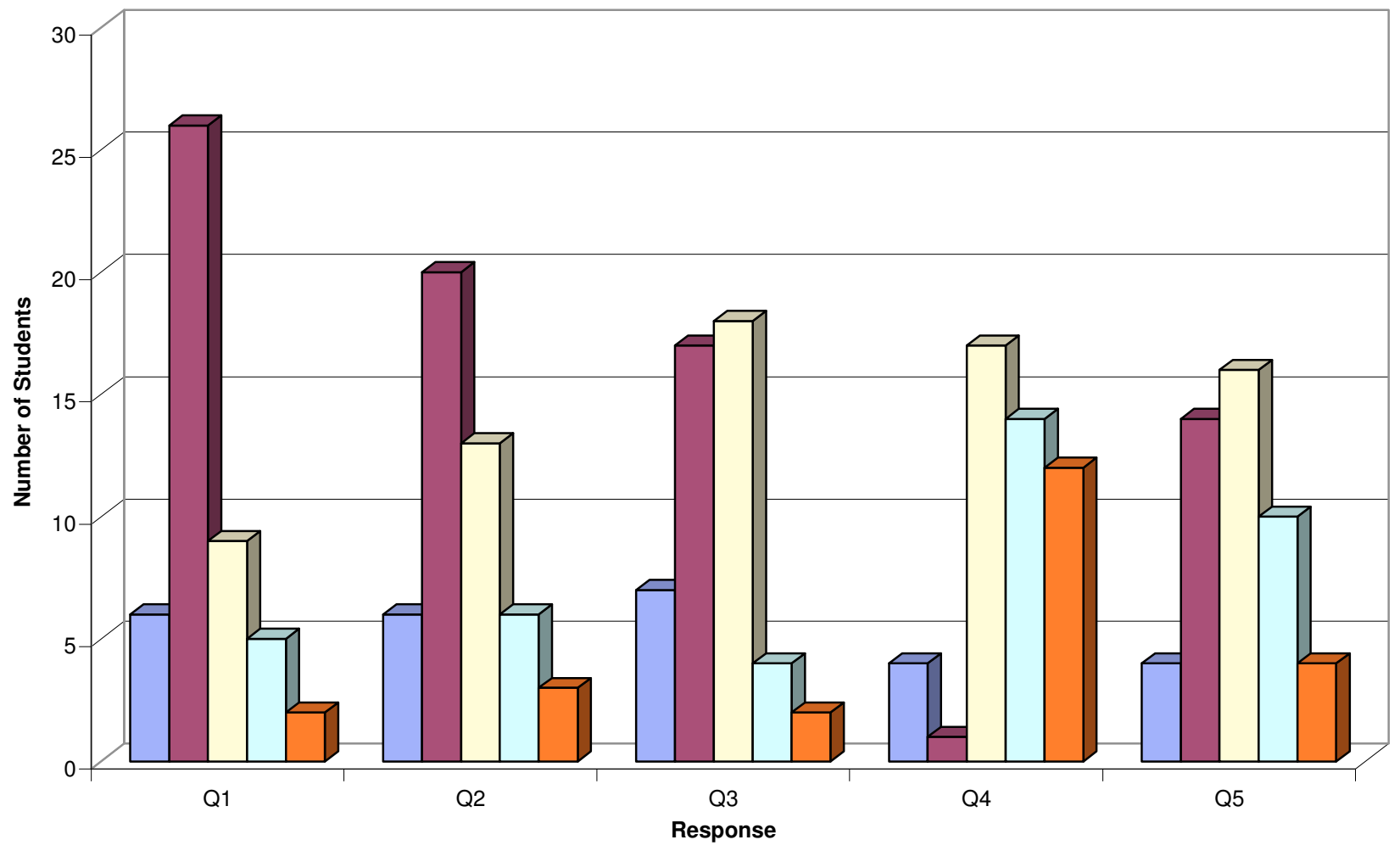

$\square$ Stongly Agree $\square$ Agree $\square$ Neutral $\square$ Disagree $\square$ Strongly Disagree

Figure 1 - Number of Responses for each Likert Category Before Implementation 
It is interesting to note that even though efforts to define the role of the advisor had not yet been implemented, 32 of 48 students (67\%) responded with either Strongly Agree or Agree to question 1. A reasonable percentage of students answered questions 2 and 3 (54\% and 50\% respectively) in a similar manner. This data, taken on its own, does not seem to indicate a major issue with project advisement, but does indicate there is room for improvement.

In addition to the Likert responses, students were also given the opportunity to provide written comments. A sampling of both positive and negative comments is included in Table 2 below. It is worth noting that negative comments outweighed positive comments by about 2 to 1 .

Table 2 - Written Comments from Student Surveys Before Implementation

Generally Positive:

- Our advisors pushed us to complete a quality project on time

- He was always making sure our industrial sponsor did not take advantage of us

- Without him, our project likely would have failed

- It was nice to have him there in case we needed him

- Didn't hold our hand but asked us great questions to think about

- He was willing to meet when we needed, and I do believe he wanted us to succeed

Generally Negative:

- Advisor should have a more structured role

- Rarely met to discuss project and progression

- Did not know the faculty advisor would be the grader/evaluator

- I am not sure how involved our advisor should be

- I would liked to have him more involved

- We didn't meet too often and didn't take the initiative to

- I feel as though an advisor should take an active role in the senior project

- More input would have been appreciated

- We should have met more

- I wish we would have had better advice earlier in the semester

- Seems some are very involved and critical while some just check on pace

- Not sure exactly what they should have done

- I think we wanted a more strict advisor

- He was there to help us but we didn't use him as much as we should

- I think he was interested but was waiting for us to come to him 
The "after" survey was completed by 44 of 44 students in the class. Figure 2 shows the number of students responding in each Likert category.

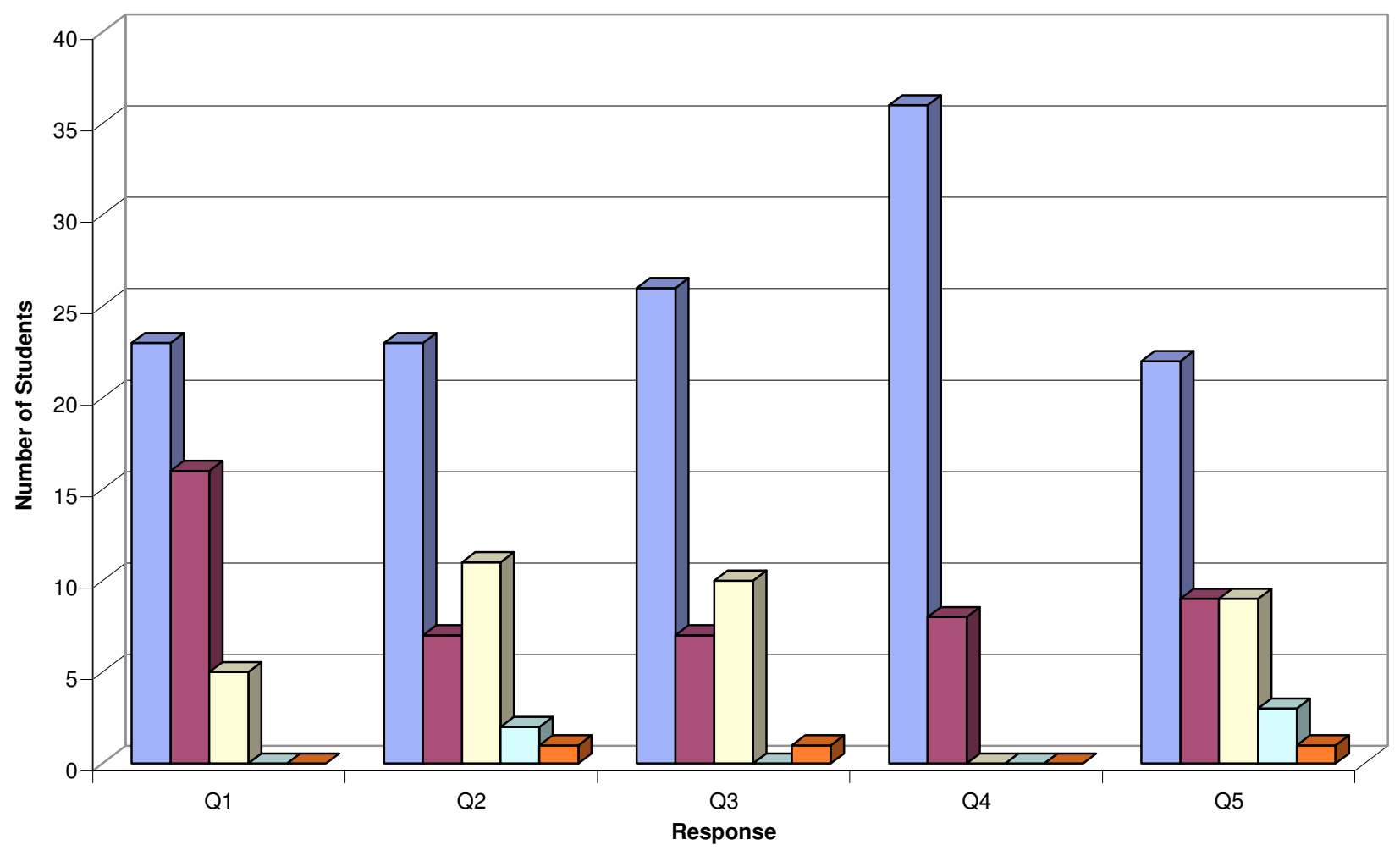

$\square$ Stongly Agree $\square$ Agree $\square$ Neutral $\square$ Disagree $\square$ Strongly Disagree

Figure 2 - Number of Responses for each Likert Category After Implementation

Even though the "before" data shown in Figure 1 are not necessarily bad, the "after" data in Figure 2 show a clear and dramatic improvement. 39 of 44 students $(89 \%)$ responded with either Strongly Agree or Agree to question 1, understanding the role of the faculty advisor. A much higher percentage of students than previous answered questions 2 and $3(68 \%$ and $75 \%$ respectively) in a similar manner, indicating a high level of satisfaction with project advisement. The striking improvement in question 4 was expected, as weekly meetings were prescribed as part of the new paradigm.

In addition to the Likert responses, written comments from the "after" survey also indicate significant improvement in project advisement. Generally positive responses slightly outnumbered negative ones, but when compared in context with the previous comments, a clear improvement is observed. A sampling of both positive and negative comments is included in Table 3 below. 
Table 3 - Written Comments from Student Surveys After Implementation

Generally Positive:
- Great feedback for presentation PowerPoints
- Very tough but in a good way
- Provided a lot of very good feedback to the group
- Our advisor for any project
- Seems excited about progrenss and asks key questions to aid the design.
- Gave us his time on a weekly basis
- Great sounding board to discuss ideas with
- Lots of help with technical issues
- There to help and guide but will not give solutions
- The feedback we got was very helpful at all our meetings
- Great advice and consistent follow-through
- Good guidance without completely giving direction
- Gave us freedom, but showed how we could improve
- Extremely helpful
Geod things about our advisor
Generally Negative:
- Other advisors did a better job at preparing their students for questions in the
- - I wosentations like to see our advisor be more like a boss, giving criticism where needed and
- direction when he sees useful
- Didvisor is unable to give clear answers
- Other advisors seemed more enthused about their projects than ours
- More involvement with the overall group activity would have been greatly appreciated
- More questions would prompt us in the right direction

As a final measure of comparison, the Likert data from both surveys was scored from 5 to1, with $5=$ Strongly Agree, $4=$ Agree, $3=$ Neutral , etc. The mean data from both surveys is shown in Figure 3. The Likert scores show a clear and dramatic improvement in the student's assessment of project advising after implementation of the paradigm. 


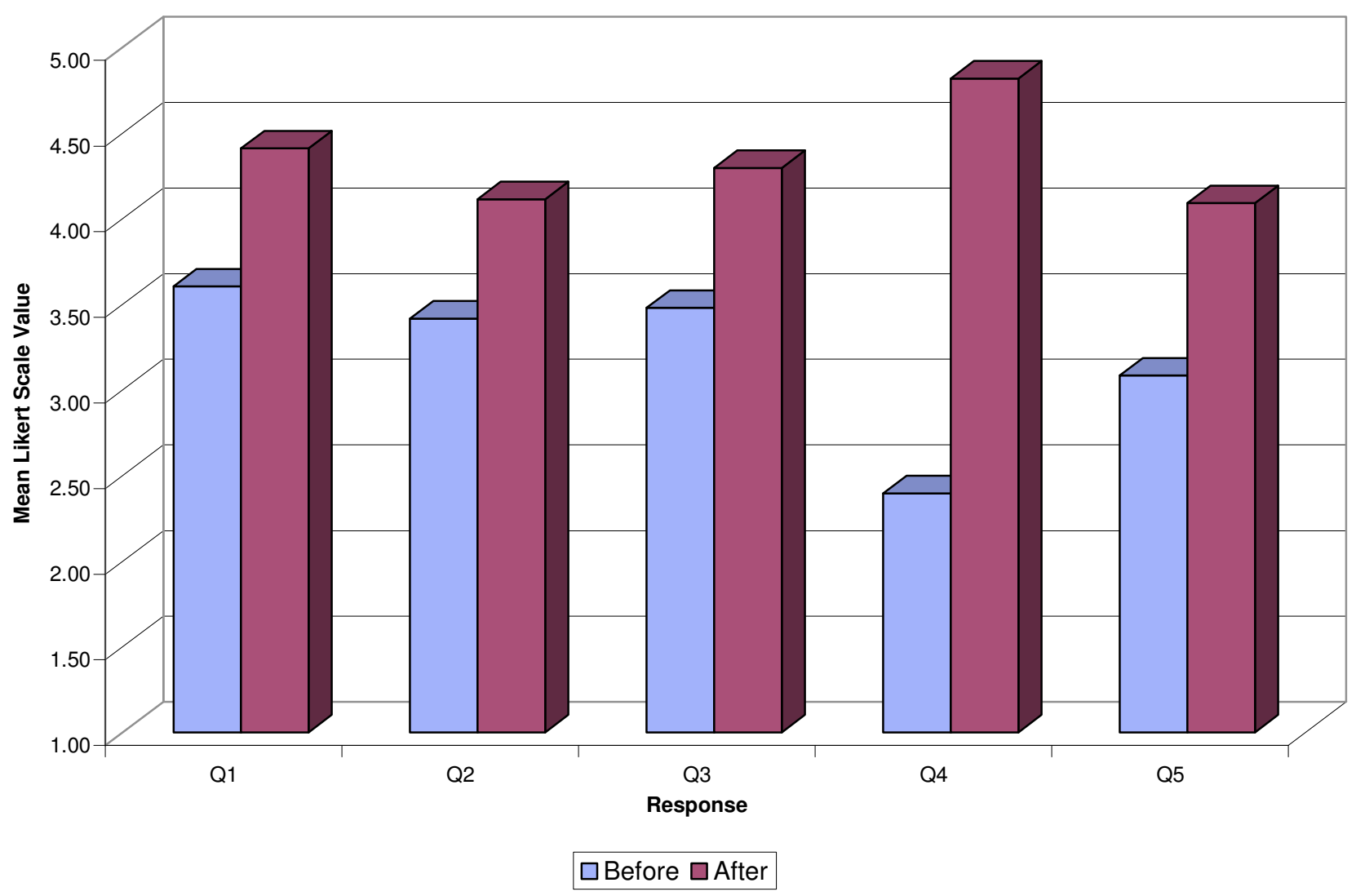

Figure 3 - Before and After Mean Likert Scores

\section{Additional Unexpected Results}

The primary goals of the project were a clearer understanding of the advisor's role by students (and faculty), more consistent advising across groups, and a better overall design experience for the students. While the overall design experience was not directly assessed, all indications are that the new model is extremely successful, has greatly improved advisement of capstone design projects, and has been a significant improvement to the curriculum.

In addition, the project has provided two unexpected benefits. One deals with another longstanding issue with respect to advisement of capstone design projects, and that is faculty workload. The department had previously not established an equitable method of assigning workload credit for project advisement. Past practice involved soliciting volunteers to advise the projects, and "spreading them around" among the faculty in an attempt to establish workload equity. Invariably, some faculty members ended up advising multiple projects while others didn't advise any. In addition, some faculty took the responsibility much more seriously than others, and time spent advising projects varied widely.

The list of responsibilities (appendix A) helped to solve this problem in two ways. First, once the list was developed, it became much easier to quantify the time commitment involved, and a 
fractional teaching credit formula was developed. Secondly, with the responsibilities defined, the advisors' workloads were much more even on a per project basis.

A second unexpected benefit of the project was clear identification of the best advisors in the department. The survey data was not anonymous, allowing comparison of individual advisors (though that was not the intent). The data showed that some advisors clearly excelled while others were less effective, at least in the eyes of the students. Interestingly enough, this pattern held in both the before and after surveys. From this data, best practices from the better advisors were solicited and discussed. These are now being implemented by all advisors in the department, further improving project advisement and the program.

\section{Conclusion}

While taking a significant amount of time and effort, development and implementation of this new paradigm for capstone design project advisement has had clear and measurable benefits. Student satisfaction has increased dramatically, project advisement has become more consistent, workload issues have been addressed, and best advising practices have been obtained and passed on.

If this project was considered for implementation at other institutions, it is expected that, while the list of actual responsibilities and other documents may look somewhat different, the process itself would produce similar positive results in other programs.

1. Somerton, C. W., Thompson, B. S., Gunn, C., The Role of the Faculty Advisor in the Capstone Design Experience: The Importance of Technical Expertise, Proceedings of the 2003 American Society for Engineering Education Annual Conference \& Exposition

2. Taylor, D. G., Magleby, S. P., Todd, R. H., \& Parkinson, A. R.). Training Faculty to Coach Capstone Design Teams., International Journal of Engineering Education, 17 (4-5) 2001

3. Gantt, L., Work, Wages and Profit, The Engineering Magazine, New York, 1910; republished as Work, Wages and Profits, Easton, Pennsylvania, Hive Publishing Company, 1974

4. Likert, Rensis, A Technique for the Measurement of Attitudes, Archives of Psychology , 140 (1-55) 1932 


\section{Appendix A - Responsibilities for Senior Project Faculty Advisors \\ Responsibilities for Senior Project Faculty Advisors}

Effective Fall 2008

It is expected that faculty members will meet with their project groups on a weekly to bi-weekly (every other week) basis, with perhaps more meetings during the fall semester than the spring. General progress should be discussed at each meeting, including a review of each student's design logbook and updates of the Gantt chart once it has been developed. Meeting Log Sheets shall be completed and kept as a record of the meetings. Milestone approvals as detailed below shall be recorded on the Faculty Advisor Approval Form. Other duties may include general project management advising, counseling individual group members on teamwork skills, and other activities in support of the learning outcomes of the course. In addition to these general duties, the following activities specific to the fall and spring semesters are expected:

Specific Duties - Fall Semester:

1. Project definition

a. Quantitative requirements, Qualitative requirements, QFD Method, ...

\section{b. Approve before project can move forward}

2. Project Proposal presentation ( week 5)

\section{a. Approve before presentation}

\section{i. Project title}

ii. Team member names and pictures

iii. Name of faculty advisor

iv. Problem description (including identifying customer)

v. Need for solution

vi. Function of device

vii. Quantitative and qualitative requirements

viii. List of deliverables 
ix. Key resources

x. Estimated budget

xi. Preliminary schedule

b. Attend presentations and participate in evaluation of all groups

i. Rubric scores for each group

ii. Written individual/group comments

3. Assist with preliminary design activities ( weeks 5 thru 10)

a. Following defined steps of the design process

b. Generating concepts (Brainstorming, Analogies, TRIZ)

c. Choosing between concepts (Pugh Analysis)

d. Project Planning (Tasks, Scheduling, Milestones, Gantt Chart)

4. Midterm peer reviews administered by course coordinator ( week 7)

a. Review peer review surveys

b. Corrective action with group members as needed

5. Preliminary Design Review presentation ( week 10)

\section{a. Approve before presentation}
i. Introduction
ii. Problem statement
iii. Specifications definition
iv. Overview of concepts developed and considered
v. Summary of development methods (brainstorming, TRIZ, ...)
vi. Finalist and winning concepts
vii. Selection criteria (must include Pugh Analysis)
viii. Gantt chart (fall and spring semesters)
ix. Budget Summary 
b. Attend presentations and participate in evaluation of all groups

i. Rubric scores for each group

ii. Written individual/group comments

6. Assist with detailed design activities ( weeks 10 thru 15)

a. Component selection, Calculations, Fabricate vs. Purchase

b. Cost estimating and budget

c. Documentation (working drawings)

7. Draft Design Report (due week 14)

a. Check for completeness

i. Background and Introduction

ii. Complete problem statement

iii. Discussion of alternative concepts

iv. Evaluation of concepts

v. Details of final solution

vi. Working drawings (top level assembly plus minimum 2 detail drawings)

vii. Gantt Chart

viii. Budget

ix. References

X. Appendices

xi. Each group member has proofread

b. Assess grade for completeness

c. Mark-up for technical content

d. Forward to course coordinator for format review

8. Final Design Review presentation ( week 15)

\section{a. Approve before presentation}



i. Introduction
ii. Problem statement
iii. Specifications definition
iv. Design solution
v. Budget

b. Attend presentations and participate in evaluation of all groups

i. Rubric scores for each group

ii. Written individual/group comments

9. Final Design Report from another team's project (exam period)
a. Complete grade rubric
b. Mark-up, comment as needed

10. Assign grade for "Overall Project Quality"

11. Assign each student's "Contribution to the Project" grade
a. Midterm peer evaluations
b. Final peer evaluations
c. Completeness of design log book
d. Other observations

Specific Duties - Spring Semester:

12. Individual Test Plans ( week 5)
a. Complete grade rubric
b. Mark-up, comment as needed
c. Assess basic competency
d. Re-assess repeat submissions

13. Final Bill of Material 


\section{a. Approve before parts may be purchased}

\section{b. Approve substitutions or changes}

14. Design fabrication

a. Manage issues of shop space and access

b. Advise on purchase vs. fabricate

15. Testing ( week 12)
a. Approve single merged test plan document
b. Witness some portion of physical testing
c. Review test results and data sheets
d. Review written summary of test results
e. Review how testing and results will be incorporated into Final Design Report
f. Assign group grade for testing and complete grade rubric

16. Final Design Presentation ( week 15)

\section{a. Approve before presentation}
i. Introduction
ii. Problem statement
iii. Specifications definition
iv. Design solution
v. Fabrication
vi. Testing
vii. Budget
viii. Future recommendations

b. Attend presentations and participate in evaluation of all groups

i. Rubric scores for each group

ii. Written individual/group comments 
17. Final Design Report from another team's project (exam period)

a. Complete grade rubric

18. Assign grade for "Overall Project Quality"

19. Assign each student's "Contribution to the Project" grade

a. Final peer evaluations

b. Completeness of design log book

c. Other observations

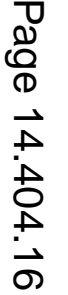


Appendix B - Faculty Advisor Meeting Log Sheet

Faculty Advisor

Date

Project Title

Students \& Logbooks:

\begin{tabular}{|l|l|l|l|} 
Student Name1 & Student Name2 & Student Name3 & Student Name4 \\
$\square$ Present at Meeting & $\square$ Present at Meeting & $\square$ Present at Meeting & $\square$ Present at Meeting \\
$\square$ Logbook Checked & $\square$ Logbook Checked & $\square$ Logbook Checked & $\square$ Logbook Checked \\
Comments: & Comments: & Comments: & Comments: \\
& & & \\
& & & \\
& & & \\
\end{tabular}

Planning / Gantt Chart:

Checked by Faculty Advisor

Updated since last meeting

Comments:

Outstanding Issues and Comments: 


\section{Appendix C - Faculty Advisor Approvals Form}

Project Title

Faculty Advisor

Problem Definition (Need, Goal, Objectives, Constraints)

(Approval required before project can move forward)

Approved

Signed

Date

Project Proposal Presentation

(Approval required before presentation can be given)

Approved

Signed

Date

Preliminary Design Review Presentation

(Approval required before presentation can be given) $\quad \square$ Approved

Signed

Date

\section{Final Design Review Presentation}

(Approval required before presentation can be given)

Approved

Signed

Date

\section{Final Bill of Material}

(Approval required before parts can be purchased)

Approved

Signed

Date

\section{Single Merged Test Plan Document}

(Approval required before testing can proceed)

Approved

Signed

Date

\section{Final Design Presentation}

(Approval required before presentation can be given)

Approved

Signed

Date 


\section{Appendix D - Grade Breakdown for Fall and Spring Courses}

MECH/MECA 440A (fall)

\begin{tabular}{|c|c|c|c|c|}
\hline Grading: & $\underline{\text { Topic }}$ & \% & $\underline{\mathrm{T} / \mathrm{I}^{*}}$ & Comment \\
\hline & $\begin{array}{l}\text { Project Proposal } \\
\text { Presentation }\end{array}$ & $5 \%$ & $\mathrm{I}$ & $\begin{array}{l}\text { Project definition, requirements, } \\
\text { presentation technique }\end{array}$ \\
\hline & $\begin{array}{l}\text { Preliminary Design } \\
\text { Review Presentation }\end{array}$ & $10 \%$ & $\mathrm{I}$ & $\begin{array}{l}\text { Conceptual design, project } \\
\text { planning, presentation technique }\end{array}$ \\
\hline & $\begin{array}{l}\text { Final Design Review } \\
\text { Presentation }\end{array}$ & $15 \%$ & I & $\begin{array}{l}\text { Final design, documentation, } \\
\text { presentation technique }\end{array}$ \\
\hline & Draft Design Report & $5 \%$ & $\mathrm{~T}$ & Completeness \\
\hline & Final Design Report & $20 \%$ & $\mathrm{~T}$ & $\begin{array}{l}\text { Content, organization, style, } \\
\text { format }\end{array}$ \\
\hline & Contribution to Project & $25 \%$ & $\mathrm{I}$ & $\begin{array}{l}\text { Peer review \& logbooks; } \\
\text { evaluated by faculty advisor. }\end{array}$ \\
\hline & Overall Project Quality & $20 \%$ & $\mathrm{~T}$ & $\begin{array}{l}\text { Quality of solution relative to } \\
\text { difficulty of project; evaluated by } \\
\text { faculty advisor. }\end{array}$ \\
\hline
\end{tabular}

MECH/MECA 440B (spring)

*T/I refers to team or individual grades

\begin{tabular}{|l|l|l|l|l|}
\hline Grading: & Topic & $\underline{\%}$ & $\underline{T} / \mathrm{l}$ & $\underline{\text { Comment }}$ \\
\hline & Individual Test Plan & $10 \%$ & $\mathrm{I}$ & $\begin{array}{l}\text { Content, organization, style, and } \\
\text { format. Evaluated by faculty advisor }\end{array}$ \\
\hline & Testing & $10 \%$ & $\mathrm{~T}$ & $\begin{array}{l}\text { Overall success of testing, data } \\
\text { collection, etc... }\end{array}$ \\
\hline & $\begin{array}{l}\text { Final Design } \\
\text { Presentation }\end{array}$ & $15 \%$ & $\mathrm{I}$ & $\begin{array}{l}\text { Content, organization, and } \\
\text { presentation technique }\end{array}$ \\
\hline & $\begin{array}{l}\text { Poster } \\
\text { Spring Design Report }\end{array}$ & $20 \%$ & $\mathrm{~T}$ & $\begin{array}{l}\text { Content, organization, style, and } \\
\text { format }\end{array}$ \\
\hline & $\begin{array}{l}\text { Contribution to } \\
\text { Project }\end{array}$ & $20 \%$ & $\mathrm{I}$ & $\begin{array}{l}\text { Peer review \& logbooks; evaluated } \\
\text { by faculty advisor }\end{array}$ \\
\hline $\begin{array}{l}\text { Overall Project } \\
\text { Quality }\end{array}$ & $20 \%$ & $\mathrm{~T}$ & $\begin{array}{l}\text { Quality of solution relative to } \\
\text { difficulty of project; evaluated by } \\
\text { faculty advisor. }\end{array}$ \\
\hline
\end{tabular}




\section{Appendix E - Faculty Advisor Survey}

The following survey is being administered to help us evaluate changes made to the supervision of senior projects. We have made numerous changes in the way projects are advised, and your input will be critical in evaluating our success in this process.

This survey is required, but is not a graded element of the course. Your name is requested only so that I can verify that it has been completed by all students in the course. Specific comments will not be shared with other faculty advisors. Thank you for your participation.

Name

Project

1. I have a clear understanding of the role of a senior project faculty advisor.

$\begin{array}{llll}\text { Strongly Agree } & \text { Agree } & \text { Neutral } & \text { Disagree }\end{array}$

Comments:

2. I have generally been pleased with the support provided by the faculty advisor of our project.

$\begin{array}{llll}\text { Strongly Agree } & \text { Agree } & \text { Neutral } & \text { Disagree }\end{array}$

Comments:

3. The faculty advisor was clearly interested in our project and did whatever he/she could to help ensure its success

$\begin{array}{llll}\text { Strongly Agree } & \text { Agree } & \text { Neutral } & \text { Disagree }\end{array}$

Comments:

4. With a few exceptions, we met weekly or at least every other week with our faculty advisor.

$\begin{array}{llll}\text { Strongly Agree } & \text { Agree } & \text { Neutral } & \text { Disagree }\end{array}$

Comments:

5. The faculty advisor contributed greatly to the success of our project.

$\begin{array}{llll}\text { Strongly Agree } & \text { Agree } & \text { Neutral } & \text { Disagree }\end{array}$

Comments: 